\title{
The 2015 regional election in Italy: fragmentation and crisis of sub-national representative democracy
}

\author{
Author: Davide Vampa \\ Affiliation: European University Institute \\ Address: (permanent) Via Dei Roccettini 50014 San Domenico di Fiesole (FI) - Italy \\ (current) Flat 583 Palmerston Road, N22 8QS, London, UK \\ Phone Numbers: 00393459228161 or 00447760458564 \\ Email: davide.vampa@eui.eu
}

Biographical note of the Author: Davide Vampa is researcher at the European University Institute, where he is completing a $\mathrm{PhD}$ project on the territorialisation of social policy in Western Europe. Part of this project has already been published in Regional and Federal Studies. He has also worked and published on political parties and elections in Italy and Western Europe. 
Abstract. In May 2015, voters in seven Italian regions went to the polls to elect new regional councils and governments. The final election result was apparently similar to that of 2010: centre-left coalitions won in five out of seven regions, like in the previous election, leaving the remaining two to the centre-right. Yet behind this picture of stability, dramatic changes have occurred in the internal composition of regional coalitions, cross-party equilibriums and levels of participation. Generally, regional party-based democracy seems to be experiencing increasing fragmentation and a crisis of representation and legitimacy.

Keywords: Italy, Regional Election, Party Politics, Electoral Participation, Sub-national Democracy

\section{Introduction}

Until 2010 regional elections had always been held on the same day in all, or almost all, 'ordinary status' ${ }^{1}$ Italian regions. Yet on the $31^{\text {st }}$ May 2015, for the first time, only seven of fifteen regions went to the polls since the remaining ones had to call early elections in previous years after their governments collapsed. This demonstrates the increasing fragmentation of Italian sub-national democracy, which, as shown below, is experiencing a period of crisis and deep transformations. Indeed, levels of electoral participation have collapsed in all the seven regions considered here and their political landscapes have also changed dramatically.

This paper is divided into two main parts. The first part consists of three sections, which describe the cross-regional differentiation in electoral systems, the main political actors involved and the declining legitimacy of regional institutions. The second part is equally formed of three sections that focus on election outcomes. First, long-term trends in electoral participation are assessed. Secondly, percentages obtained by individual lists are analysed and it is shown that mainstream parties have lost many votes to local lists, with electoral volatility reaching its highest point in twenty years. The third section of this part considers the composition of regional councils and, by looking at levels of fragmentation

\footnotetext{
${ }^{1}$ Fifteen Italian regions are defined as 'ordinary status' and they have less fiscal and policy-making autonomy than the remaining five 'special status' regions.
} 
and disproportionality, suggests that it is difficult to detect common patterns of representative democracy across the regions analysed.

Part 1

\section{Seven regions, seven voting systems}

As underlined by Pallarés and Keating (2003: 244) in their analysis of multi-level electoral competition in Spain, 'the electoral system helps to explain the specific pattern of party systems and also the relationships between territorial levels'. Italy is the only case among European decentralised systems in which regions have been free to adopt significantly different voting systems (Floridia, 2005). Not only do the regional voting systems diverge from the national one but they also substantially differ from each other. This has led to cross-regional fragmentation in the mechanisms that translate votes into political representation. Table 1 presents a summary of the different voting systems in place in the seven regions analysed in this paper. As it can be seen, although they have all adopted proportional voting systems, which also allow for the formation of multi-party coalitions, regional electoral laws have established different thresholds for individual parties and coalitions of parties. Additionally, winning coalitions are granted majority bonuses that vary in magnitude from region to region, also depending on the percentage of votes obtained by the winning coalition. Tuscany is also the only case in which a two-round electoral system, if no candidate for president obtains at least $40 \%$ of the vote, has been introduced. In sum, the institutional rules that shape regional party competition are extremely fragmented and, often, very complicated.

The only common feature is that regional presidents are all directly elected. Therefore, whereas at the national level Italy can still be classified as a parliamentary democracy (Lijphart, 1992), regional systems are moving closer to the presidential model. This has led to a more general process of 'presidentialisation' of regional politics (Poguntke and Webb, 2005), which, in turn, has had an impact on the quality of the political offer, with the sharp increase in the number of 'personal' local lists supporting the candidates for regional presidency. 
[Table 1 about here]

\section{Parties, programmes, coalitions and the rise of 'local lists'}

The 2015 election was an important political test in a context of deep transformations in the Italian party system. The section provides a brief overview of the programmatic and coalition strategies pursued by the four largest parties competing in the election. ${ }^{2}$

The Democratic Party (PD) is a centre-left party and the main party in central government. Its young leader and Italian Prime Minister, Matteo Renzi, has started a process of radical economic and social reforms, which have been strongly criticized by the more traditional factions of his own party. In 2014, Renzi transformed the European election campaign into a sort of referendum on his government, which had been formed only three months before. The PD achieved its best result ever obtaining around $40 \%$ of the vote (Valbruzzi and Vignati, 2014). On the occasion of the 2015 regional election, however, Renzi played a much less active role in the candidate selection and in the electoral campaign. In five out of seven regions, supporters and members were given the opportunity to participate in open primaries to select the candidates for the presidency. Also in terms of programmatic platforms, the PD did not adopt a homogeneous strategy across the seven regions. In Tuscany, for instance, the regional party branch presented a traditional manifesto that also referred to the actions taken by the party leadership in central government. In Apulia the party organisation played a marginal role in the construction of the platform, which was instead a bottom-up process of deliberation open to the local population, completely focused on regional issues and directly promoted by the candidate for regional presidency without party mediation. In Veneto, the PD candidate did not even present a complete programme but, instead, relied on a list of very short slogans.

Over the last two years, the Northern League (LN) has transformed from a purely regionalist party into a right-wing, populist party with state-wide political aspirations.

\footnotetext{
${ }^{2} \mathrm{~A}$ list of the party platforms mentioned below is provided in the appendix.
} 
Under the new leadership of Matteo Salvini, the party has sought to become an Italian version of the French Front National and has started to campaign in regions in which it was not traditionally strong. The new strategy of territorial expansion is reflected in the party's electoral campaign, which was totally dominated by the party leader and mainly focused on national issues and on the opposition to the central government (and to the European Union). Yet some differences can be noted in LN manifestos presented across the regions. In Veneto, an old stronghold of the League, the traditional themes of autonomy, federalism and even regional independence, were clearly mentioned in the party programme. On the other hand, in Tuscany, the party adopted a different programmatic strategy, which completely ignored the issues of regionalism and federalism but, instead, focused on national (or even supra-national) issues, such as the economic crisis, immigration and law and order.

The mainstream, centre-right party led by Silvio Berlusconi - renamed 'Italy Forward' (Forza Italia, FI) in 2014- did not adopt a clear political platform in the 2015 election. In some regions, like Liguria, a traditional manifesto was not even presented. In Umbria, the party passively accepted the programmatic points suggested by an 'independent' candidate. In general, the absence of a clear national strategy, swinging from supporting to opposing the Renzi government, was also reflected in the lack of strong electoral messages during the electoral campaign.

Finally, the Five Star Movement (M5S), an 'anti-system' political force that obtained a very strong result in the 2013 general election, focused its campaign on issues such transparency in public institutions, environmentalism and the creation of a 'basic income' across the whole Italian territory. Yet some 'formal' differences can be noted in the programmes presented at the regional level. Whereas in Liguria the M5S candidate presented a very extensive and detailed programme, in Apulia the manifesto was very brief and vague, basically a series of power point slides. It should also be underlined that, unlinke in the previous elections, the national leader of the M5S, the comedian Beppe Grillo, did not play an active role in the election campaign, which was mainly led by young regional candidates together with a group of national representatives of the Movement.

The last electoral round demonstrates the increasing fragmentation of coalition strategies pursued by political parties in the regional arena. Italy may be seen as an 
exception in the European context, since the electoral systems adopted by its regions encourage the formation of coalitions before (and not after) the elections. Table 2 shows how competition has changed across the seven regions from 2005 until the last election. If in 2005 competition was mainly between broad, centre-left and centre-right coalitions, today the picture is much more fragmented. For instance, far left parties are no longer part of centreleft coalitions (dominated by the PD) in most of the regions, whereas centre-right parties have formed comprehensive coalitions (including LN, FI and smaller parties) only in Liguria, Umbria and Campania. Additionally, centre parties have established alliances with different coalitions depending on the regional context. Finally, the emergence of the Five Star Movement has further complicated the map of political competition in the Italian regions.

[Table 2]

The increasing weakness of the links between central and regional party organisations may be regarded as one of the main causes of the less consistent coalition and programmatic strategies pursued at the sub-national level. Italian statewide parties seem to have developed new 'stratarchical' organisational structures (Carty, 2004; Katz and Mair, 2009). In this context, national leaders are still able (and willing) to control the selection of national representatives and define the national strategy of the party, whereas local and regional organisations are free to adopt different programmatic and coalition strategies depending on the regional context (Van Biezen and Hopkin, 2006).

Electoral competition in Italian regions is no longer 'monopolised' by political parties, since new 'local lists' have emerged and multiplied in recent years. Even though such lists have been studied mainly in municipal electoral contexts (Reise and Holtmann, 2008), the Italian case seems to suggest that they may also play an important role at the 'meso-level'. Local lists are different from political parties, even from regionalist parties, because they do not rely on any kind of integrated organisation and formal membership. They participate exclusively in electoral competitions to select the council and president of one specific region (i.e. they are not cross-territorial organisations and they do not compete in general elections). Additionally, they often refer to the name of a specific candidate 
(personal lists) and, although they might form coalitions with political parties, they reject identifiable partisan labels (often they call themselves 'civic lists', to underline their nature as bottom-up networks of 'free citizens').

The number of local lists participating in regional elections has increased substantially in the last election, as shown in Table 3. Even compared to the 2010 election, the number of non-partisan lists presented in the 2015 regional elections has more than doubled, from 15 to 38. Therefore, it seems that Italian parties are losing their appeal in the regional arena and, in order to maintain their support, often 'outsource' representation to lists that are not formally recognizable as 'partisan'. Indeed, Pritoni (2014: 390) has argued that mainstream Italian parties often choose to promote local lists as part of a 'blame avoidance' strategy aimed at attracting the votes of those citizens, who are increasingly sceptical of purely party-based politics. Veneto and Campania are the two regions where this phenomenon has been more noticeable.

[Table 3 about here]

\section{The crisis of legitimacy of regional governments}

The last contextual factor that should be taken into account when analysing regional election results in Italy, is the crisis of political legitimacy faced by regional institutions. A Demos survey published at the end of $2014^{3}$ shows that since 2010, Italians' support for regional institutions has dropped from $33 \%$ to $19 \%$, a decline of 14 percentage points that is even greater than in the case of municipalities (-12\%) and national parliament (-6\%).

The whole political system of Italy has experienced years of turbulence and instability since the beginning of the economic crisis in the late 2000s. Yet regions seem to have been particularly hit by the wave of protest politics. This is also due to the various corruption or expenses scandals that have involved regional governments and councils in the last years (Cerruto, 2013). Additionally, the 2015 electoral campaign was characterised

\footnotetext{
${ }^{3} \underline{\text { http://www.demos.it/a01077.php (date of access 27/06/2015) }}$
} 
by a heated debate on regional candidates that were involved in judicial proceedings (the socalled impresentabili, "unpresentable candidates"). In sum, regions have come to be seen as clear examples of corrupted political elites and diffuse misgovernment.

\section{Part 2}

\section{The collapse in political participation}

Aggregate turnout in the seven regions has reached the lowest point in the last election. Table 4 shows that, since 1990, turnout has collapsed from $86.4 \%$ to $52.3 \%$. Even compared to the previous electoral round, turnout in 2015 has dropped by 11 percentage points. Interestingly, the largest decline in turnout has been experienced in Tuscany and Marche, two regions that used to lead the ranking of political participation in Italy and now have turnouts below 50\%. Thus, changes in Italian sub-national democracy have been quite radical and have overturned well-established traditions. Studies focusing on the transformation of advanced representative democracies (see, for instance, Mair 2005) have pointed to a trend of decreasing electoral participation in national elections. In the Italian case such trend seems even more accentuated at the regional level (participation in national elections has 'only' declined from $87 \%$ in 1992 to $75 \%$ in 2013).

[Table 4 about here]

\section{The declining appeal of political parties}

At first sight, the overall result of this election was not different from that in 2010: centre-left coalitions led by the Democratic Party won in five out of seven regions. Whereas ruling coalitions did not change in 4 regions, Campania shifted from the centre-right to the centreleft and Liguria experienced an opposite swing. Yet if we look at the results obtained by individual parties we immediately notice that, compared to the previous election, the political landscape in the seven regions has been radically transformed. 
As shown in Table 5, only two parties have not experienced a significant change in their overall support. The Democratic Party (PD), has confirmed its 2010 result (around $25 \%$ ), increasing its vote share in Tuscany and Marche, while experiencing small losses in the other five regions. Also the Northern League (LN) has achieved an aggregate result that is very similar to that of 2010, although it has become substantially stronger in central Italian regions such as Tuscany, Umbria and Marche, whereas in Veneto it seems to have lost many votes to local lists (although the strongest local list in Veneto is the 'personal' list of the LN candidate for president).

The real loser of the election is the mainstream, centre-right party Forward Italy (FI). Whereas this party was the strongest one in 2010, today it has collapsed to around one third of its original vote share, with a more marked decline in central-northern regions. Today the leadership of the centre-right coalition is increasingly challenged by the Northern League, which, as shown by the election results, has ceased to be a regionalist political force, mainly based in the North, and has managed to expand its electoral support to the Centre and even the South of Italy (indeed, for the first time, the party achieved a 2.4\% in Apulia).

Lastly, the Five Star Movement (M5S) achieved a respectable 15\% across the seven regions, scoring its best results in Liguria and Marche. The Movement has thus consolidated its role as second political force in the Italian political system (a role that it already achieved in 2013 and 2014).

However, the most notable result in the last electoral round is the strengthening of local, 'non-partisan' lists. As already underlined, the number of lists that cannot be directly identified as political parties (although they can still establish alliances with statewide and regionalist parties) has substantially increased over the last 25 years. Yet it seems that in the last election, their aggregate electoral score has risen even more significantly, from $7.6 \%$ in 2010 to almost 20\%. Going back to 1990, it can be noted that the 2015 election is a 'critical juncture' in the crisis of partisan politics at the regional level (Figure 1). From the early 1990s until 2010, the increase in electoral support for local lists was gradual and, in any case, did not seem to challenge the predominance of partisan political actors. With the 2015 election, instead, local lists have come to control almost one fifth of the vote in the seven regions and this should be seen as a clear sign of declining electoral appeal of organised political parties in the regional arena. 
[Table 5 about here]

[Figure 1 about here]

In sum, the political landscape of Italian regions seems to have changed quite radically. This is further confirmed by the magnitude of electoral volatility, calculated by using the Pedersen index (see Bartolini and Mair, 1990) ranging from 0 (no volatility) to 100 (full volatility). In Table 6, 2015 is compared to 2010 but also to 1995, when levels of volatility were the highest in the history of Italian regionalism due to the collapse of the old party system in the early 1990s. We can see that volatility in 2015 is much closer to that of the 'earthquake' election in 1995 than to those of the more 'ordinary' election in 2010.

[Table 6 about here]

\section{Representation in the seven regions}

Table 7 provides an overview of the regional councils elected in 2015. First of all it considers the share of seats won by the main forces participating in the elections. The PD is by far the largest party across the seven regional councils obtaining around $35 \%$ of the seats, thus increasing its representation compared to 2010. FI and the LN have obtained similar shares of seats, around $10 \%$, but, overall, they are both behind the M5S, which, therefore, is the second party also in terms of representation. It should also be noted that whereas the LN has increased its representation, particularly in Liguria and in central regions such as Tuscany, Umbria and Marche, FI has experienced a dramatic collapse. The composition of regional councils seems to indicate the existence of a 'dominant' party on the centre-left (the PD) and of a rather fragmented opposition, in which no party emerges as the leading one. 
Additionally, the declining representation of other, small or medium-sized, parties $(-10 \%)$ seems to have been counterbalanced by a general strengthening of local lists $(+11.3 \%)$.

Finally, the nature of party systems resulting from the interaction between real votes and electoral formulas is considered. As already shown, regions adopted different voting systems and this may have led to increasing cross-regional divergence in the types of electoral democracy. This seems to be confirmed by some preliminary results shown in Table 7. First, one can consider the level of party fragmentation within the newly elected councils (that is, the 'effective' number of parties or lists that obtained representation), which is measured by using the Laakso Taagepera (1979) index. Secondly, the 'disproportionality' between votes and seats may be assessed by using the Gallagher (1991) index (least squares index): the higher the value, the higher the discrepancy between votes and seats. Whereas regions such as Tuscany, Umbria and Marche have moved towards less fragmented and more disproportional systems of representation, thus developing more 'majoritarian' characteristics (Lijphart, 1999), Veneto and Liguria have moved in the opposite direction, since they now have more fragmented and proportional systems than in 2010. In between, we find the cases of Campania and Apulia, where a substantial increase in fragmentation is accompanied by an increase in disproportionality (although this increase is minimal in the case of Apulia). The picture is therefore extremely heterogeneous and it is not possible to detect a clear pattern of development across the seven regions.

\section{[Table 7 about here]}

\section{Conclusion}

This paper has sought to provide an analysis of the recent election results in seven Italian regions. The context of the 2015 regional election has been thoroughly investigated: the elections were affected by differentiation in regional electoral systems, the strategies pursued by political parties, and the crisis of legitimacy of regional institutions. The analysis of the election outcomes can be summarised in three points. First of all, electoral participation has significantly dropped. Secondly, statewide parties have been increasingly challenged by non-partisan, local lists; the levels of electoral volatility have been exceptionally high. Finally, regional party systems seem to be following diverging 
trajectories of development. It means that regional party-based democracy in Italy appears to be experiencing increasing fragmentation.

\section{Appendix: list of party manifestos mentioned in this study (by party)}

\section{PD/ Centre-Left:}

Veneto: http://www.alessandramoretti.it/programma/

Tuscany: http://www.pdtoscana.it/wp-content/uploads/PROGRAMMA-REGIONALI20151.pdf

Apulia: http://www.micheleemiliano.it/

\section{Northern League:}

Veneto: http://lucazaia.it

Tuscany: http://naz-toscana.leganord.org/programma_leganord_elezioni_regionali_2015.pdf

\section{FI/Centre-right}

Liguria: manifesto not found

Umbria: http://www.riccipresidente.it/wp-content/uploads/2015/05/RICCI_Programma_xweb.pdf

\section{Star Movement:}

Liguria: http://www.alicesalvatore.it/stella-1-sviluppo-economico/

Apulia: http://www.antonellalaricchia.it/wp-content/uploads/2015/04/Programma-

Regionali-2015-rev.-6.pdf

\section{Reference}

Bartolini, S. and P. Mair (1990), Identity, Competition and Electoral Availability: The stabilisation of European electorates 1885-1985. Cambridge and New York: Cambridge University Press.

Carty, R. K. (2004), Parties as Franchise Systems: The Stratarchical Organizational Imperative, Party Politics, Vol. 10, No. 1: 5-24.

Cerruto, M. (2013), La delegittimazione della classe politica regionale. Istituzioni del Federalismo: Rivista di studi giuridici e politici, Vol. 34, No. 2, pp. 477-507.

Floridia, A. (2005), Le nuove leggi elettorali regionali: molte occasioni mancate, alcune novitá positive, Le Regioni, No. 5, pp. 841-870. 
Gallagher, M. (1991), Proportionality, Disproportionality and Electoral Systems, Electoral Studies, Vol. 10, No. 1, pp. 33-51.

Katz, R. S. and P. Mair (2009), The Cartel Party Thesis: A Restatement, Perspectives on Politics, Vol. 7, No. 4, pp. 753-766.

Laakso, M. and R. Taagepera (1979), Effective Number of Parties: A Measure with Application to West Europe, Comparative Political Studies, Vol. 12, No. 1, pp. 3-27.

Lijphart, A. (ed.) (1992), Parliamentary versus Presidential Government. Oxford and New York: Oxford University Press.

Lijphart, A. (1999), Patterns of Democracy: Government Forms and Performance in Thirty-Six Countries. London and New Heaven: Yale University Press.

Mair, P. (2005), Democracy Beyond Parties, Center for the Study of Democracy, Working Paper 05-06. Available at http://repositories.cdlib.org/csd/05-06

Pallarés and Keating (2003), Multi-level Electoral Competition: Regional Elections and Party Systems in Spain, European Urban and Regional Studies, Vol. 10, No. 3, pp. 239-255.

Poguntke, T. and P. D. Webb (eds.) (2005), The Presidentialization of Politics: A Comparative Study of Modern Democracies, Oxford and New York: Oxford University Press.

Pritoni, A. (2014), Le comunali in Piemonte, Lombardia, Liguria e Veneto: c'era una volta il Nord (di destra), in M.

Reise, M. and E. Holtmann (eds.) (2008), Farewell to the Party Model Independent Local Lists in East and West European Countries. Wiesbaden: VS Verlag für Sozialwissenschaft.

Valbruzzi, M. and R. Vignati (eds.), L'Italia e L'Europa al bivio delle riforme: Le elezioni europee e amministrative del 24 maggio 2014. Bologna: Istituto Carlo Cattaneo.

Van Biezen, I. and J. Hopkin (2006), Party organisation in multi-level contexts, in D. Hough and C. Jeffery (eds.), Devolution and electoral politics. Manchester and New York: Manchester University Press, pp. 14-36. 
Table 1. Voting systems in the seven regions involved in the 2015 election round

\begin{tabular}{|c|c|c|c|}
\hline & $\begin{array}{l}\text { Number } \\
\text { of seats }\end{array}$ & Thresholds & Majority Bonus \\
\hline Veneto & $50\left(+1^{*}\right)$ & $\begin{array}{l}\mathbf{3} \% \text { for party in a coalition } \\
\text { obtaining at least } 10 \% \text {. } \\
\text { Otherwise } 5 \% \text {. }\end{array}$ & $\begin{array}{l}30 \text { seats (out of } 50 \text { ) if coalition obtains } \\
50 \% \text { of the vote } \\
29 \text { seats if winning coalition obtains } \\
\text { between } 40 \text { and } 50 \% \text { of votes } \\
28 \text { of seats if winning coalition obtains } \\
\text { less than } 40 \% \text { of seats }\end{array}$ \\
\hline Liguria & $30(+1)$ & $\begin{array}{l}\text { No threshold for party if } \\
\text { candidate for president } \\
\text { obtains at least } 5 \% \text {. } \\
\text { Otherwise } 3 \% \text {. }\end{array}$ & $\begin{array}{l}\text { Winning coalition obtains } 6 \text { extra seats } \\
\text { (blocked list) }\end{array}$ \\
\hline Tuscany & $40(+1)$ & $\begin{array}{l}3 \% \text { for party in a coalition } \\
\text { obtaining } 10 \% \text {. Otherwise } \\
5 \% \text {. }\end{array}$ & $\begin{array}{l}24 \text { seats (out of } 40 \text { ) if winning coalition } \\
\text { obtains more than } 45 \% \text { of the vote } \\
23 \text { seats if winning coalition obtains less } \\
\text { than } 45 \% \text { of the vote } \\
\text { Second round if no candidate for } \\
\text { president obtains } 40 \% \text { of the vote }\end{array}$ \\
\hline Umbria & $20(+1)$ & $2.5 \%$ for any party & $\begin{array}{l}\text { Winning coalition always obtains } 12 \\
\text { out of } 20 \text { seats }\end{array}$ \\
\hline Marche & $30(+1)$ & $\begin{array}{l}\text { No threshold for party in } \\
\text { a coalition obtaining } 5 \% \text {. } \\
\text { Otherwise } 3 \% \text {. }\end{array}$ & $\begin{array}{l}18 \text { seats (out of } 30 \text { ) if winning coalition } \\
\text { obtains at least } 40 \% \text { of the vote } \\
17 \text { seats if winning coalition obtains } \\
\text { between } 37 \text { and } 40 \% \text { of the vote } \\
16 \text { seats if winning coalition obtains } \\
\text { between } 34 \text { and } 37 \% \text { of the vote }\end{array}$ \\
\hline Campania & $50(+1)$ & $\begin{array}{l}\text { No threshold for party if } \\
\text { candidate for president } \\
\text { obtains at least } 10 \% \text {. } \\
\text { Otherwise } 3 \% \text {. }\end{array}$ & $\begin{array}{l}30 \text { to } 32 \text { seats (out of } 50 \text { ) for the } \\
\text { winning coalition }\end{array}$ \\
\hline Apulia & $50(+1)$ & $\begin{array}{l}4 \% \text { for party in a } \\
\text { coalition. Otherwise } 8 \% \text {. }\end{array}$ & $\begin{array}{l}29 \text { seats (out of } 50 \text { ) if winning coalition } \\
\text { obtains at least } 40 \% \text { of the vote } \\
28 \text { seats if winning coalition obtains } \\
\text { between } 35 \text { and } 40 \% \text { of the vote } \\
27 \text { seats if winning coalition obtains less } \\
\text { than } 35 \% \text { of the vote }\end{array}$ \\
\hline
\end{tabular}

*The elected regional president is also a member of the regional council.

Sources: Websites of regional governments (http://www.regione.liguria.it/; http://www.regione.veneto.it; http://www.regione.toscana.it/; $\quad$ http://www.regione.umbria.it; $\quad$ http://www.regione.campania.it/; http://www.regione.puglia.it/) and cise.luiss.it 
Table 2. Main coalitions participating in regional elections from 2005 to 2010

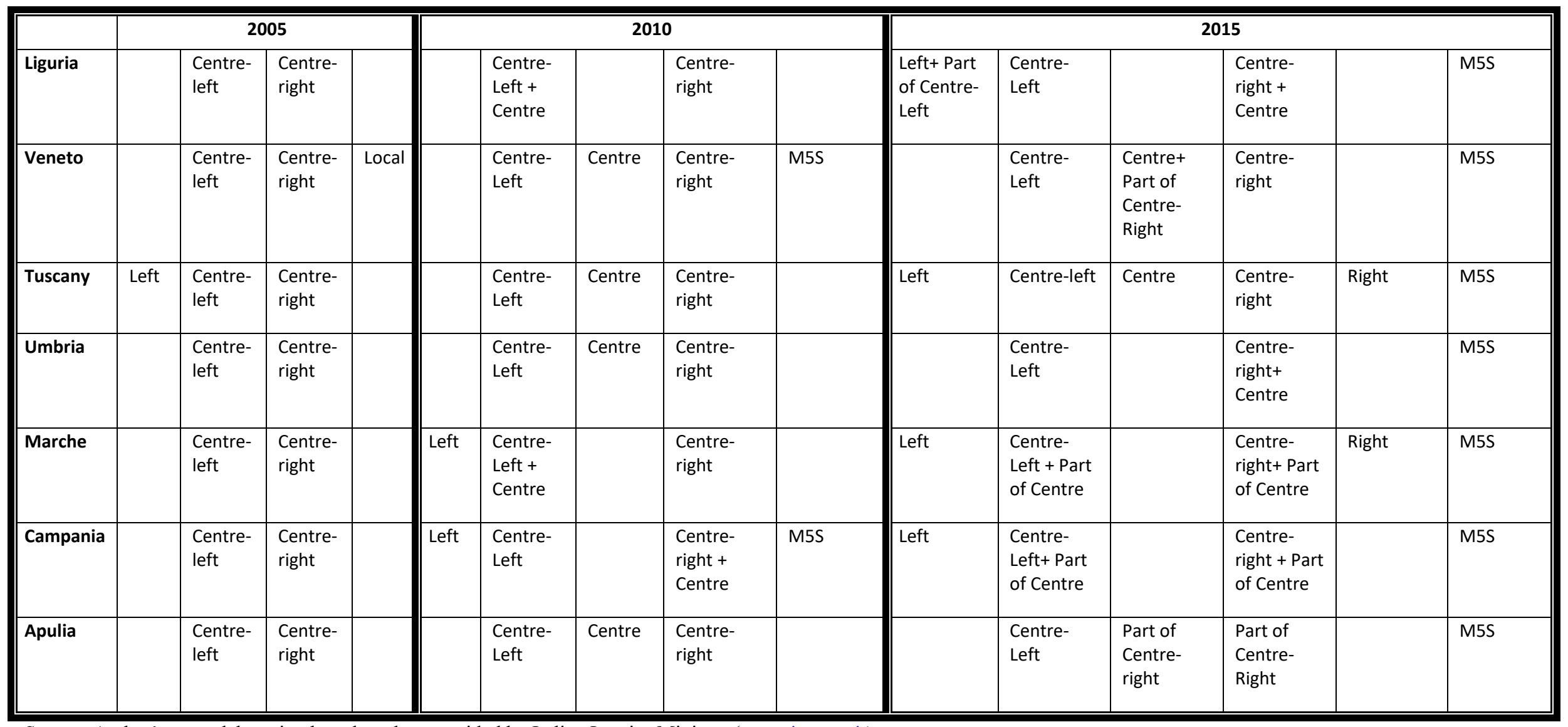

Source: Author's own elaboration based on data provided by Italian Interior Ministry (www.interno.it). 
Table 3. Local lists participating in regional elections from 1990 to 2015

\begin{tabular}{|l|r|r|r|r|r|r|}
\hline & $\mathbf{1 9 9 0}$ & $\mathbf{1 9 9 5}$ & $\mathbf{2 0 0 0}$ & $\mathbf{2 0 0 5}$ & $\mathbf{2 0 1 0}$ & $\mathbf{2 0 1 5}$ \\
\hline Liguria & 0 & 3 & 1 & 3 & 3 & 5 \\
\hline Veneto & 0 & 1 & 3 & 4 & 4 & 11 \\
\hline Tuscany & 1 & 0 & 1 & 0 & 0 & 3 \\
\hline Umbria & 0 & 1 & 0 & 0 & 0 & 5 \\
\hline Marche & 1 & 0 & 1 & 1 & 2 & 2 \\
\hline Campania & 1 & 1 & 2 & 3 & 2 & 8 \\
\hline Apulia & 0 & 1 & 1 & 3 & 4 & 4 \\
\hline Total & 3 & 7 & $\mathbf{9}$ & $\mathbf{1 4}$ & $\mathbf{1 5}$ & $\mathbf{3 8}$ \\
\hline
\end{tabular}

Source: Author's own elaboration based on data provided by Italian Interior Ministry (www.interno.it). 
Table 4. Declining turnout in Italian regions 1990-2015

\begin{tabular}{|l|r|r|r|r|r|r|r|r|}
\hline & $\mathbf{1 9 9 0}$ & $\mathbf{1 9 9 5}$ & $\mathbf{2 0 0 0}$ & $\mathbf{2 0 0 5}$ & $\mathbf{2 0 1 0}$ & $\mathbf{2 0 1 5}$ & $\begin{array}{l}\text { Difference } \\
\text { 2015/2010 }\end{array}$ & \multicolumn{2}{l|}{$\begin{array}{l}\text { Difference } \\
\mathbf{2 0 1 5 / 1 9 9 0}\end{array}$} \\
\hline Liguria & 84.8 & 80 & 70.4 & 69.6 & 60.9 & 50.7 & -10.2 & -34.1 \\
\hline Veneto & 90.8 & 85.2 & 75.6 & 72.4 & 66.4 & 57.2 & -9.2 & -33.6 \\
\hline Tuscany & 89.6 & 85.2 & 74.6 & 71.4 & 60.7 & 48.8 & -11.9 & -40.8 \\
\hline Umbria & 90.6 & 85.6 & 76.8 & 74.3 & 65.4 & 55.4 & -10 & -35.2 \\
\hline Marche & 89.4 & 84.6 & 74.3 & 71.5 & 62.8 & 49.8 & -13 & -39.6 \\
\hline Campania & 81.1 & 73.9 & 69.5 & 67.7 & 63 & 51.9 & -11.1 & -29.2 \\
\hline Apulia & 84.2 & 75.7 & 70.2 & 70.5 & 63.2 & 51.2 & -12 & -33 \\
\hline Total & $\mathbf{8 6 . 4}$ & $\mathbf{8 0 . 1}$ & $\mathbf{7 2 . 4}$ & $\mathbf{7 0 . 4}$ & $\mathbf{6 3 . 3}$ & $\mathbf{5 2 . 3}$ & $\mathbf{- 1 1}$ & $\mathbf{- 3 4 . 1}$ \\
\hline
\end{tabular}

Source: Italian Interior Ministry (www.interno.it). Author's own elaboration. 
Table 5. Election results by party and winning coalitions (in the last column). Difference with previous election in brackets.

\begin{tabular}{|c|c|c|c|c|c|c|c|}
\hline & $\begin{array}{r}\text { Democratic } \\
\text { Party (PD) } \\
\end{array}$ & $\begin{array}{l}\text { Forward } \\
\text { Italy (FI) }\end{array}$ & $\begin{array}{r}\text { Northern } \\
\text { League (LN) } \\
\end{array}$ & $\begin{array}{c}\text { Five Star } \\
\text { Mov. (M5S) }\end{array}$ & Other parties & Local lists & Winning coalition \\
\hline Liguria & $\begin{array}{r}25.6 \\
(-2.7)\end{array}$ & $\begin{array}{r}12.7 \\
(-16.6)\end{array}$ & $\begin{array}{r}20.3 \\
(+10.1)\end{array}$ & $\begin{array}{r}22.3 \\
(+22.3)\end{array}$ & $\begin{array}{r}10.4 \\
(-10.3)\end{array}$ & $\begin{array}{r}8.8 \\
(-1.7)\end{array}$ & $\begin{array}{l}\text { Centre-right: FI, LN, } \\
\text { others } \\
\text { (Centre-left) }\end{array}$ \\
\hline Veneto & $\begin{array}{r}16.7 \\
(-4.3)\end{array}$ & $\begin{array}{r}6 \\
(-18.7)\end{array}$ & $\begin{array}{r}17.8 \\
(-17.4)\end{array}$ & $\begin{array}{r}10.4 \\
(+7.8)\end{array}$ & $\begin{array}{r}6.6 \\
(-8.4)\end{array}$ & $\begin{array}{r}42.6 \\
(+40.4)\end{array}$ & $\begin{array}{l}\text { Centre-right: LN, FI, } \\
\text { others } \\
\text { (Centre-right) }\end{array}$ \\
\hline Tuscany & $\begin{array}{r}46.3 \\
(+4.1) \\
\end{array}$ & $\begin{array}{r}8.5 \\
(-18.6) \\
\end{array}$ & $\begin{array}{r}16.2 \\
(+9.7) \\
\end{array}$ & $\begin{array}{r}15.1 \\
(+15.1) \\
\end{array}$ & $\begin{array}{r}11.6 \\
(-11.7) \\
\end{array}$ & $\begin{array}{r}2.3 \\
(+1.4) \\
\end{array}$ & $\begin{array}{l}\text { Centre-left: PD } \\
\text { (Centre-left) }\end{array}$ \\
\hline Umbria & $\begin{array}{r}35.8 \\
(-0.4)\end{array}$ & $\begin{array}{r}8.5 \\
(-23.9)\end{array}$ & $\begin{array}{r}14 \\
(+9.7)\end{array}$ & $\begin{array}{r}14.6 \\
(+14.6)\end{array}$ & $\begin{array}{r}18.5 \\
(-8.6)\end{array}$ & $\begin{array}{r}8.6 \\
(+8.6)\end{array}$ & $\begin{array}{l}\text { Centre-left: PD, Left, } \\
\text { others } \\
\text { (Centre-left) }\end{array}$ \\
\hline Marche & $\begin{array}{l}35.1 \\
(+4)\end{array}$ & $\begin{array}{r}9.4 \\
(-21.8)\end{array}$ & $\begin{array}{r}13 \\
(+6.7)\end{array}$ & $\begin{array}{r}18.9 \\
(+18.9)\end{array}$ & $\begin{array}{r}18.5 \\
(-7.9)\end{array}$ & $\begin{array}{r}5 \\
(+0.1)\end{array}$ & $\begin{array}{l}\text { Centre-left: PD, } \\
\text { others } \\
\text { (Centre-left) }\end{array}$ \\
\hline Campania & $\begin{array}{r}19.5 \\
(-1.9)\end{array}$ & $\begin{array}{r}17.8 \\
(-13.9)\end{array}$ & $\begin{array}{r}0 \\
(=)\end{array}$ & $\begin{array}{r}17 \\
(+15.7)\end{array}$ & $\begin{array}{r}24 \\
(-6)\end{array}$ & $\begin{array}{r}21.6 \\
(+14.1)\end{array}$ & $\begin{array}{l}\text { Centre-left: PD, } \\
\text { others } \\
\text { (Centre-right) }\end{array}$ \\
\hline Apulia & $\begin{array}{r}19.8 \\
(-1)\end{array}$ & $\begin{array}{r}11.4 \\
(-19.7)\end{array}$ & $\begin{array}{r}2.4 \\
(+2.4)\end{array}$ & $\begin{array}{r}17.2 \\
(+17.2)\end{array}$ & $\begin{array}{r}34.3 \\
(+6.5)\end{array}$ & $\begin{array}{r}15 \\
(-5.3)\end{array}$ & $\begin{array}{l}\text { Centre-left: PD, Left, } \\
\text { others } \\
\text { (Centre-left) }\end{array}$ \\
\hline Total & $\begin{array}{r}25.2 \\
(-0.7)\end{array}$ & $\begin{array}{r}11.3 \\
(-18.9)\end{array}$ & $\begin{array}{r}9.6 \\
(-0.3)\end{array}$ & $\begin{array}{r}15.7 \\
(+14.8)\end{array}$ & $\begin{array}{r}18.7 \\
(-7.8)\end{array}$ & $\begin{array}{r}19.6 \\
(+12)\end{array}$ & $\begin{array}{l}\text { Centre-left: } 5 \text { regions } \\
\text { Centre-right: } 2 \\
\text { regions }\end{array}$ \\
\hline
\end{tabular}


Table 6. Volatility in 1995, 2010 and 2015

\begin{tabular}{|l|r|r|r|}
\hline & $\mathbf{1 9 9 5}$ & $\mathbf{2 0 1 0}$ & $\mathbf{2 0 1 5}$ \\
\hline Liguria & 51.2 & 20 & 48 \\
\hline Veneto & 61.1 & 30 & 57.3 \\
\hline Tuscany & 43.2 & 18.9 & 36 \\
\hline Umbria & 52.8 & 23 & 42.8 \\
\hline Marche & 54.5 & 22.4 & 50 \\
\hline Campania & 65.1 & 37.9 & 43.4 \\
\hline Apulia & 62.1 & 32.2 & 55.4 \\
\hline Average & 55.7 & 26.3 & 47.6 \\
\hline
\end{tabular}

Source: Source: Italian Interior Ministry (www.interno.it). Author's own elaboration. 
Table 7. Regional representation by party (\% of seats), fragmentation and disproportionality in newly elected councils (difference with previous election in brackets)

\begin{tabular}{|c|c|c|c|c|c|c|c|c|}
\hline & \multicolumn{6}{|c|}{ Share of seats won \% } & \multirow{2}{*}{$\begin{array}{l}\text { Fragmentation } \\
\text { (Laakso Taagepera } \\
\text { index) }\end{array}$} & \multirow{2}{*}{$\begin{array}{l}\text { Disproportionality } \\
\text { (Gallagher index) }\end{array}$} \\
\hline & $\begin{array}{l}\text { Democratic } \\
\text { Party (PD) }\end{array}$ & $\begin{array}{l}\text { Forward } \\
\text { Italy (FI) }\end{array}$ & $\begin{array}{l}\text { Northern } \\
\text { League (LN) }\end{array}$ & $\begin{array}{l}\text { Five Star } \\
\text { Movement (M5S) }\end{array}$ & Local Lists & $\begin{array}{l}\text { Other } \\
\text { Parties }\end{array}$ & & \\
\hline Liguria & $\begin{array}{r}25.8 \\
(-10.8)\end{array}$ & $\begin{array}{r}19.4 \\
(-7.5)\end{array}$ & $\begin{array}{r}22.6 \\
(+15.3)\end{array}$ & $\begin{array}{r}19.4 \\
(+19.4)\end{array}$ & $\begin{array}{r}0 \\
(-7.3)\end{array}$ & $\begin{array}{r}12.9 \\
(-9.1)\end{array}$ & $\begin{array}{r}5 \\
(+0.6)\end{array}$ & $\begin{array}{r}6.9 \\
(-0.3)\end{array}$ \\
\hline Veneto & $\begin{array}{r}17.6 \\
(-7.9)\end{array}$ & $\begin{array}{r}5.9 \\
(-22)\end{array}$ & $\begin{array}{r}21.6 \\
(-12.9)\end{array}$ & $\begin{array}{r}9.8 \\
(+9.8)\end{array}$ & $\begin{array}{r}43.1 \\
(+41.5)\end{array}$ & $\begin{array}{r}2 \\
(-9.5)\end{array}$ & $\begin{array}{r}6.1 \\
(+2.3)\end{array}$ & $\begin{array}{r}4 \\
(-0.8)\end{array}$ \\
\hline Tuscany & $\begin{array}{r}61 \\
(+15.5)\end{array}$ & $\begin{array}{r}4.9 \\
(-26)\end{array}$ & $\begin{array}{r}14.6 \\
(+9.2)\end{array}$ & $\begin{array}{r}12.2 \\
(+12.2)\end{array}$ & $\begin{array}{r}0 \\
(=)\end{array}$ & $\begin{array}{r}7.3 \\
(-10.9)\end{array}$ & $\begin{array}{r}2.4 \\
(-0.7)\end{array}$ & $\begin{array}{r}11.2 \\
(+6.6)\end{array}$ \\
\hline Umbria & $\begin{array}{l}52.4 \\
(+4)\end{array}$ & $\begin{array}{r}4.8 \\
(-21)\end{array}$ & $\begin{array}{r}9.5 \\
(+6.3)\end{array}$ & $\begin{array}{r}9.5 \\
(+9.5)\end{array}$ & $\begin{array}{r}9.5 \\
(+9.5)\end{array}$ & $\begin{array}{r}14.3 \\
(-8.3)\end{array}$ & $\begin{array}{l}3.2 \\
(=)\end{array}$ & $\begin{array}{r}13.9 \\
(+3.5)\end{array}$ \\
\hline Marche & $\begin{array}{r}51.6 \\
(+15.2)\end{array}$ & $\begin{array}{r}6.5 \\
(-23.1)\end{array}$ & $\begin{array}{r}9.7 \\
(+5.1)\end{array}$ & $\begin{array}{r}16.1 \\
(+16.1)\end{array}$ & $\begin{array}{r}6.5 \\
(+4.2)\end{array}$ & $\begin{array}{r}9.7 \\
(-17.6)\end{array}$ & $\begin{array}{l}3.2 \\
(-1)\end{array}$ & $\begin{array}{r}12.7 \\
(+8.3)\end{array}$ \\
\hline Campania & $\begin{array}{r}31.4 \\
(+8.4)\end{array}$ & $\begin{array}{r}15.7 \\
(-20.4)\end{array}$ & $\begin{array}{r}0 \\
(=)\end{array}$ & $\begin{array}{r}13.7 \\
(+13.7) \\
\end{array}$ & $\begin{array}{r}21.6 \\
(+11.8)\end{array}$ & $\begin{array}{r}17.6 \\
(-13.5)\end{array}$ & $\begin{array}{r}6.3 \\
(+1.5)\end{array}$ & $\begin{array}{r}10.3 \\
(+5.5)\end{array}$ \\
\hline Apulia & $\begin{array}{r}27.5 \\
(+0.2)\end{array}$ & $\begin{array}{r}11.8 \\
(-18.2)\end{array}$ & $\begin{array}{r}0 \\
(=)\end{array}$ & $\begin{array}{r}13.7 \\
(+13.7)\end{array}$ & $\begin{array}{r}17.6 \\
(+1.9)\end{array}$ & $\begin{array}{r}29.4 \\
(+2.3)\end{array}$ & $\begin{array}{r}6.8 \\
(+2.9)\end{array}$ & $\begin{array}{r}1 \\
(+0.2)\end{array}$ \\
\hline Total & $\begin{array}{r}35.7 \\
(+2.9)\end{array}$ & $\begin{array}{r}10.1 \\
(-19.9)\end{array}$ & $\begin{array}{r}10.5 \\
(+2.3)\end{array}$ & $\begin{array}{r}13.5 \\
(+13.5)\end{array}$ & $\begin{array}{r}16.6 \\
(+11.3)\end{array}$ & $\begin{array}{l}13.7 \\
(-10)\end{array}$ & --- & --- \\
\hline
\end{tabular}

Source: Source: Italian Interior Ministry (www.iterno.it). Author's own elaboration. 
Figure 1. Overall support for local lists in the seven regions (1990-2015)

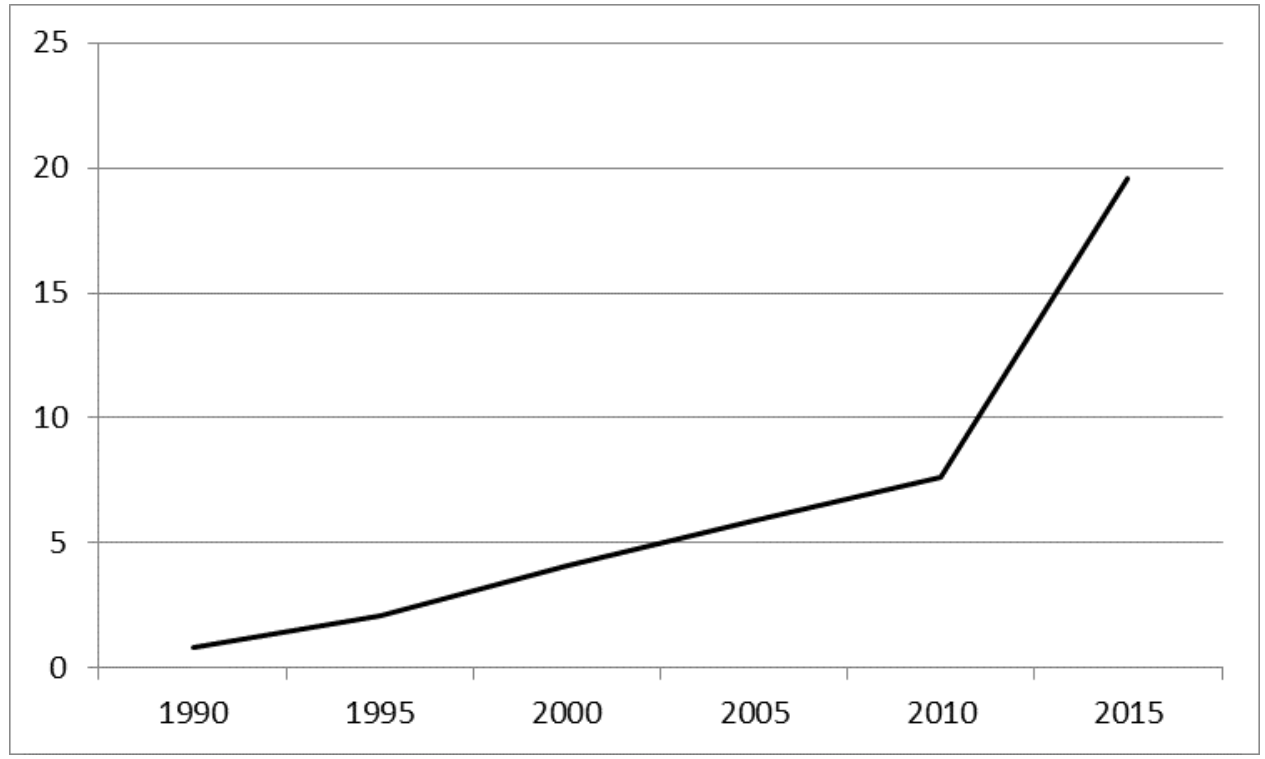

Source: Italian Interior Ministry. Author's own elaboration. 